The Cult of the Goldfish. By T. C. Roughley. Pp. xiii $+146+29$ plates. (Sydney: Angus and Robertson, Ltd.; London: Australian Book Co., 1933.) 6s. net.

MR. RovGHLEY has written perhaps the best book on gold-fish culture that has yet been published. It is a most useful volume, well produced and full of interest from beginning to end. The author thoroughly understands his fish and shows how they will respond to considerate treatment. Those who read these pages will never wish to keep a gold-fish in a bowl again, but they certainly will wish to keep a real aquarium and care for the fish in it; moreover, directions are given for making the aquarium or pond at home, which must appeal to many craftsmen.

The varieties of gold-fish are numerous and new kinds are constantly appearing. Breeding gold-fish is an exciting occupation and apparently not so very difficult if care be given to essentials. The aquarium made, one is taught how to supply it with suitable plants. The varieties of gold-fish are discussed and their food, also which animals may be put in with them to advantage and which should be avoided. There are chapters on spawning and development, the garden pool, animal pests in ponds and diseases of gold-fish.

Not only are the life-histories of the food animals discussed, but also those of the diseases to which the fish are subject and of those animals which may be found in the pond. Thus the mosquito is useful as the larvæ are a good food, pond beetles and dragonflies are harmful, the larvæ eating the young fishes. The information given on the diseases which so often affect gold-fish is extremely interesting and full remedies are discussed.

Virus Diseases of Plants. By Dr. John Grainger. Pp. viii $+104+6$ plates. (London: Oxford University Press, 1934.) 6s. net.

Our knowledge of the plant viruses has increased enormously in the last decade. We have not yet, however, arrived at any definite conclusion as to the nature of this interesting group of pathogens. In this book, the whole problem of virus diseases and their etiology is compressed into seventy-five pages, with, in addition, twenty-five pages of bibliography. The first chapter is devoted to a very short account of the general subject. The second deals with the relation of the virus to its host plant-with special reference to some of the better known viruses. It is not quite certain that the suggestions in the section on cytology, that a $1 / 12$ in. oil immersion lens is necessary for the examination of the $X$-bodies and that these bodies frequently disappear by the erosion of the protoplasmic stream, would meet with general acceptance among cytologists. Chap. iii is devoted to the physical and chemical properties of the virus so far as these are known. The fourth chapter deals with the important problem of the insect transmission of the disease and gives some meagre notes on the treatment of insects under experi- mentation. The chapter on the economic effects and the control of the disease is probably the most useful in the book. It deals with methods for preventing the spread of the disease. The classification and description of virus diseases is dealt with in chap. vi.

This book will be of use mainly as a general account of the plant virus problem.

Celtic Ornament in the British Isles down to A.D. \%00. By E. T. Leeds. Pp. xix $+170+22$ plates. (Oxford: Clarendon Press; London: Oxford University Press, 1933.) 12s. 6d. net.

In this study of Celtic ornament, Mr. E. T. Leeds has elaborated a communication presented to the first International Congress of Pre- and Protohistoric Sciences in 1932. It is a survey of the subject as a whole from the earliest appearance of distinctively Celtic art after the coming of the early Iron Age peoples to Britain down to the beginning of Anglo-Saxon times. The various types of characteristic motifs are traced in the finds from initiation to decay and their relations and distributions analysed. Such detailed discussion was eminently desirable, as nothing of a similarly comprehensive nature had been attempted since Romilly Allen's work on Celtic art in pagan and Christian times of more than thirty years ago. In the meantime, not only has the material which Allen had before him come to be more clearly understood, but also much new material has accrued, bringing with it a clearer appreciation of the problems which call for solution. Mr. Leeds's views on the renaissance of Celtic art after the Romano-British eclipse, especially when they differ from those of Mr. T. D. Kendrick, will repay careful consideration.

\section{Neurological Effects of Syphilis: Diagnosis and} Treatment. By Dr. B. Buckley Sharp. (Oxford Medical Publications.) Pp. v +92 . (London: Oxford University Press, 1933.) 7s. 6d. net.

Dr. B. Buckley Sharp has provided us with a very interesting book on neurosyphilis; but it might very well have been larger. There are several statements with which we are inclined to find fault. To state categorically that "there are no clinical entities exclusively syphilitic" is a misstatement. There is no better-defined clinical entity than general paralysis, which is in 100 per cent cases exclusively syphilitic. Again, vascular lesions are present in certainly 80 per cent of neurosyphilitics.

The author appears to be prejudiced in favour of including intracisternal salvarsanzed serum in treatment, for he says he and Purves Stewart have never seen a return to a normal fluid without using this treatment. This is not the experience of the majority. The section dealing with diathermy might well have been expanded; a large amount of work has been done on this form of treatment. A $2 \mathrm{gm}$. dose of tryparsamide is just as satisfactory as $3 \mathrm{gm}$. and much safer. 